\title{
Observational study in adult hypopituitary patients with untreated growth hormone deficiency (ODA study). Socio-economic impact and health status
}

\author{
Anna Sanmartî ${ }^{1}$, Anna Lucas ${ }^{1}$, Federico Hawkins ${ }^{2}$, Susan M Webb ${ }^{3}$ and Angels Ulied ${ }^{4}$ on behalf of the \\ Collaborative ODA (Observational GH Deficiency in Adults) Group \\ ${ }^{1}$ Hospital Universitari Germans Trias i Pujol, Badalona (Barcelona), Spain, ${ }^{2}$ Hospital 12 de Octubre, Madrid, Spain, ${ }^{3}$ Hospital Santa Creu i Sant Pau, \\ Barcelona, Spain and ${ }^{4}$ Medical Department, Pharmacia and Upjohn, St Cugat del Vallès, Barcelona, Spain \\ (Correspondence should be addressed to A Sanmartí, Endocrinology Service, Hospital Universitari Germans Trias i Pujol, Carretera del Canyet \\ s/n (Can Ruti), 08916-Badalona (Barcelona), Spain; Email: asanmarti@ns.hugtip.scs.es)
}

\begin{abstract}
Objective: The aim of the present study was to assess the socio-economic impact at baseline and after one year of follow-up of clinical and health status characteristics and laboratory tests of adult-onset GH deficiency (AGHD), a well-known clinical entity, in a large group of Spanish hypopituitary patients with untreated AGHD.

Design and Methods: A total of 926 eligible patients with $\mathrm{GHD}(\mathrm{GH} \leq 5 \mathrm{ng} / \mathrm{ml}$ after stimulation) and at least one further pituitary hormone deficiency were retrospectively studied; 356 of these were followed for one year. Complete physical examination, IGF-I, lipid and routine biochemistry measurements and health-related quality of life (HRQoL) with the specific QoL-Assessment of Growth Hormone Deficiency in Adults (AGHDA) questionnaire were assessed at baseline and at 12 months in the prospective study. Health status and health-economic evaluation were measured by a specific questionnaire and a patient diary and compared with Spanish population study results.

Results: Clinical characteristics and laboratory tests of AGHD showed a higher incidence of cardiovascular risk factors and mortality compared with the general population (hypercholesterolaemia in $29 \%$ vs $18 \%$ and hypertension in $22.1 \%$ vs $14.9 \%$ ). QoL-AGHDA scores for patients were significantly worse $(P<0.01)$ and direct health costs were higher than in the general population.

Conclusions: Hypopituitary GHD adults had more cardiovascular risk factors, higher mortality, worse HRQoL and higher absolute health costs than the general population in Spain.
\end{abstract}

European Journal of Endocrinology $141481-489$

\section{Introduction}

Growth hormone (GH) deficiency (GHD) in children leads to impaired growth and consequently short final height. Substitution therapy with GH in children has proved to favour linear growth and is normally used in this kind of patient. Although GH is secreted throughout life, its role in adulthood has only been studied in the last few years. GHD in adults is now a recognized clinical entity characterized by an increase in total fat mass, a reduction in lean body mass, reduced exercise capacity, decreased bone mass and impaired psychological well-being $(1-6)$. On the other hand, therapy with $\mathrm{GH}$ in $\mathrm{GH}$-deficient adult patients has been shown to normalize body composition, increase bone density and cardiac function, improve physical and health-related quality of life (HRQoL), raise insulin-like growth factor (IGF)-I serum levels and may exert beneficial effects on lipid metabolism (7-14).
At present, trials in GHD adults are mainly focused on assessing short- and long-term health consequences of the deficiency and its substitution treatment with GH. The more extensive and detailed our knowledge of the clinical, psychological and social features of this population, the more rational our use of $\mathrm{GH}$ in these patients can be. To date, information on these features, particularly socio-economic aspects and HRQoL in a large group of patients who acquire GHD in adulthood has been scant (15). Therefore, a retrospective evaluation and one-year follow-up in a large group of Spanish patients with GHD acquired in adulthood, who were not treated with GH, was undertaken.

\section{Objectives}

The first objective was to undertake a study of Spanish GHD patients who acquired GH deficiency in adulthood 
(cross-sectional study). The second objective was to evaluate a sufficiently large group of these patients with respect to clinical and laboratory tests, HRQoL and, particularly, socio-economic aspects and health status at baseline and after 12 months of follow-up (longitudinal study).

\section{Subjects and methods}

\section{Cross-sectional study}

For the first objective, 926 eligible patients (485 females, 441 males; mean age: 53.3 years; S.D.: 14.7) from hospital records of endocrinology units of 37 reference hospitals distributed in the 17 Spanish autonomous regions were included. Inclusion criteria required patients to suffer from hypothalamic-pituitary disease and GH deficiency (GH values $\leq 5 \mathrm{ng} / \mathrm{ml}$ after a standard stimulation test), to have at least one other pituitary hormone deficiency, to be on stable and adequate replacements of the other non-GH pituitary deficiencies and to be aged $\geq 18$ years at diagnosis. Acromegalic and previously GH-treated patients were excluded. Hospital records were reviewed for demographic data, aetiology of GH deficiency, GH stimulation tests and age at diagnosis. Pituitary disease therapy and cause of death, if it occurred, were also obtained from the hospital records.

\section{Longitudinal study}

A total of 356 patients (201 females, 155 males; mean age: 52.4 years; S.D.: 13.6) of the initial 926 were included in the follow-up study. Additional criteria required to enter this study were standard and stable replacement treatment for other pituitary hormone deficiencies for at least six months prior to inclusion, and GH deficiency diagnosed at least 12 months before. Recruitment period for this follow-up study was six months to avoid any time bias in the health year cost evaluation. Exclusion criteria were previous GH treatment and gonadotrophin deficiency with no oestrogen substitution therapy in women $\leq 50$ years of age. These 356 patients were evaluated at baseline and after 12 months, when findings were compared with the baseline studies.

\section{Methods}

Physical examination Physical examination included weight, height, body mass index (BMI), waist-hip ratio and blood pressure. Results were compared with reference standards of an adult Spanish population.

Laboratory evaluation Hormone evaluation included serum concentrations of thyrotrophin, free or total thyroxine $\left(\mathrm{T}_{4}\right)$ and free or total testosterone. $\mathrm{GH}$ deficiency was confirmed after insulin-hypoglycaemia $(95.7 \%)$ or another test $(4.3 \%)$, with patients on stable substitution for other pituitary hormone deficiencies. Serum IGF-I samples at baseline were analysed by a competitive radioimmunoassay (RIA). Serum IGF binding protein (IGFBP)-3 at baseline was measured by an enzyme-linked immunosorbent assay (ELISA) developed by Diagnostic System Laboratories Inc. (Webster, TX, USA). Both measurements were centralized in Pharmacia \& Upjohn Laboratories - Peptide Hormones, Stockholm, Sweden. Patients were studied at baseline and at 12 months for blood analysis, electrolytes, general biochemistry with a lipid profile (total cholesterol, triglycerides, low and high density lipoprotein (LDL and HDL) cholesterol), liver and kidney function measured by standard techniques.

\section{Health-related quality-of-life (HRQoL) assessment} The Assessment of Growth Hormone Deficiency in Adults questionnaire (QoL-AGHDA) is a self-administered instrument specifically designed to evaluate HRQoL in GHD adults (16-18). The instrument was designed for use in clinical trials and the routine monitoring of GHD patients. It was developed in the United Kingdom from transcripts of in-depth interviews with adult GHD patients, which were analysed to determine which aspects of the condition were most commonly cited as incapacitating patients in the achievement of their needs. It has been translated and validated in several languages (Swedish, German, Italian and Spanish), thereby providing an instrument suitable for use in international studies (16-18). The QoL-AGHDA contains 25 items with a yes/no response format. The total score is obtained by totalling the number of affirmative answers indicating presence of HRQoL problems with possible scores ranging from 0 (best HRQoL) to 25 (worst HRQoL). Data are expressed as mean scores and 95\% confidence intervals (CI) adjusted for age and education level. Patients were compared with a random Spanish population sample of 963 subjects matched for age and sex to figures of the Spanish census.

Health status evaluation The survey conducted by CIRES (Centro de Investigaciones Sobre la Realidad Social) included assessment of the following areas: state of health during the last year, health habits, social aspects (income, job, educational level, psychological or mood status) and economic data. In each hospital, the questionnaire was answered by the patients and conducted by the same interviewer. These results were compared with those obtained with the same survey carried out in a control population sample of 1200 normal Spanish subjects in February 1994 (19).

Health-economic evaluation In order to ascertain the economic impact of hypothalamic-pituitary disease in adults in Spain, 356 patients were followed by their regular visits and a yearly clinical and HRQoL assessment throughout the observation period to quantify the 
annual cost of disease by measuring direct and indirect costs $(20,21)$. The patients kept a diary to indicate all health care-related visits, days off from work and medication taken. We considered hypothalamic-pituitary disease as a whole because of the difficulty in separating isolated GH deficiency. Direct costs were calculated by adding the drug cost to the retail prices (hormone substitution: thyroxine, hydrocortisone acetate, gonadal steroids and antidiuretic hormone and other concomitant therapies) including taxes to the direct medical costs associated with the direct provision of healthcare services (physician services and hospitalizations). Accepting that the salary received by the worker is a good indicator of the value of lost production due to disability through illness, we transformed the days on leave into monetary units. Indirect costs were associated with loss of productivity, earnings lost from days off from work, calculated by the Spanish mean employee earnings (40.9 US dollars (USD)/day) (figures from the Spanish Ministry of Labour and Health Service) adjusted by unemployment data (National Statistics Institute Survey of active population) which was $22.8 \%$ during the study period (31.6 USD/day). Annual patient costs were used to estimate the economic impact of the disease according to prevalence. The 'bottom-up' approach was used for health-economic evaluation and forms a base for disease cost calculation. It studies the consumption of resources employed during the study period of a specified number of patients. The mean health cost is multiplied by the estimated prevalence. Results were compared with the health costs of the Spanish general population adjusted to 1993 data according to the retail price index (RPI) (22). The most important variables for economic evaluation in chronic diseases are age and evolution time; thus, both were considered in the study $(23,24)$. Non-medical and intangible costs were not evaluated.

Data analysis Data were analysed with SPSS for Windows and/or CIA (confidence interval analysis; M J Gardner and British Medical Journal version 1.0, 1989). Comparison between groups (groups defined by variables such as sex, age or type of hormone deficiency) was made for qualitative variables by a $\chi^{2}$ test, for continuous variables which satisfy parametric test application conditions by Student's $t$-test, and for non-parametric variables the Mann-Whitney U test was used. Relationships between two quantitative variables were analysed by Pearson's or Spearman's correlation coefficient, depending on the variable nature. Quantitative dichotomy variables were compared by McNemar's test. Comparisons between ODA patients and the normal population from the CIRES survey was tested using 95\% confidence interval (CI) for difference in proportion tests. Other CI referred to in the text are also $95 \%$. Significance was established in a two-sided test set to the 0.05 level.

\section{Results}

\section{Cross-sectional study}

Demographic data are shown in Table 1. Aetiology of hypopituitarism was: non-functional pituitary tumour in $39.4 \%$ and functional pituitary tumour in $21.3 \%$; non-pituitary tumour: craniopharyngioma $11.2 \%$, meningioma $1.4 \%$ and others $2.7 \%$; Sheehan's syndrome represented $10.0 \%$, empty sella $5.2 \%$ and other causes $8.8 \%$ of the total 926 patients. GH peak concentrations between $3-5 \mathrm{ng} / \mathrm{ml}$ were found in $7.9 \%$ and below $3 \mathrm{ng} / \mathrm{ml}$ in the rest. Patients with GHD with one additional pituitary hormone deficiency represented $13.4 \%$, with two additional pituitary hormone deficiencies $23.0 \%$ and panhypopituitary patients comprised $63.6 \%$. Diabetes insipidus was diagnosed in $30.0 \%$. The majority of these patients with pituitary tumours had received both surgery and radiotherapy for their treatment (40.8\%), surgery alone was applied in $29.1 \%$ and other treatments in $30.1 \%$ of patients. Mean evolution time of GH deficiency was 8.7 years (s.D. $=6.8$; range: $1-$ 34 years). Deaths registered in 34 clinical records were due to the following causes: cardiovascular disease (stroke, pulmonary thrombo-embolism and coronary disease) in 15 patients (44.1\%), malignant diseases in 7 $(20.6 \%)$ and other causes in 12 (35.3\%).

\section{Longitudinal study}

Demographic data are shown in Table 1. Aetiology of hypopituitarism was: non-functional pituitary tumour

Table 1 Demographic data.

\begin{tabular}{|c|c|c|c|c|c|c|}
\hline \multirow[b]{2}{*}{ Age groups } & \multicolumn{3}{|c|}{ Women } & \multicolumn{3}{|c|}{ Men } \\
\hline & $\begin{array}{l}\text { Cross-sectional } \\
\text { study }\end{array}$ & $\begin{array}{l}\text { Longitudinal } \\
\text { study }\end{array}$ & $P$ & $\begin{array}{c}\text { Cross-sectional } \\
\text { study }\end{array}$ & $\begin{array}{l}\text { Longitudinal } \\
\text { study }\end{array}$ & $P$ \\
\hline $\begin{array}{l}<35 \text { years } \\
35-50 \text { years } \\
50-60 \text { years } \\
>65 \text { years }\end{array}$ & $\begin{array}{l}10.2 \% \\
30.7 \% \\
31.9 \% \\
27.1 \%\end{array}$ & $\begin{array}{r}9.6 \% \\
26.9 \% \\
39 \% \\
24.4 \%\end{array}$ & $\begin{array}{l}\text { ns } \\
\text { ns } \\
\text { ns } \\
\text { ns }\end{array}$ & $\begin{array}{l}16.9 \% \\
24.6 \% \\
36.8 \% \\
21.6 \%\end{array}$ & $\begin{array}{l}16.1 \% \\
30.8 \% \\
41.7 \% \\
11.4 \%\end{array}$ & $\begin{array}{l}\text { ns } \\
\text { ns } \\
\text { ns } \\
\text { ns }\end{array}$ \\
\hline Number & 485 (52.4\%) & $201(56.5 \%)$ & ns & $441(47.6 \%)$ & 155 (43.5\%) & ns \\
\hline
\end{tabular}


Table 2 Physical examination. Longitudinal study.

\begin{tabular}{|c|c|c|c|c|c|c|}
\hline & \multicolumn{3}{|c|}{ Women } & \multicolumn{3}{|c|}{ Men } \\
\hline & $\begin{array}{l}\text { Baseline } \\
(n=201)\end{array}$ & $\begin{array}{l}12 \text { months } \\
(n=181)\end{array}$ & $P$ & $\begin{array}{l}\text { Baseline } \\
(n=155)\end{array}$ & $\begin{array}{c}12 \text { months } \\
(n=139)\end{array}$ & $P$ \\
\hline Weight (kg) $(\overline{\mathrm{X}}(\mathrm{s} . \mathrm{D}))$. & $70.4(12.6)$ & $77.6(15.3)$ & ns & $83.1(14.7)$ & $78.4(16.3)$ & ns \\
\hline Height $(\mathrm{cm})(\overline{\mathrm{X}}(\mathrm{S} . \mathrm{D}))$. & $154.9(7.1)$ & - & - & $168.0(7.8)$ & - & - \\
\hline BMI $\left(\mathrm{kg} / \mathrm{m}^{2}\right)(\bar{X}(\mathrm{~S} . \mathrm{D}))$. & $29.3(5.1)$ & $30.3(6.2)$ & ns & $29.0(4.2)$ & $29.8(4.5)$ & $\mathrm{ns}$ \\
\hline $\begin{array}{l}\text { BMI (\%) } \\
\quad<25 \\
25.0-29.9 \\
\geq 30.0\end{array}$ & $\begin{array}{l}20.8 \\
38.3 \\
41.0\end{array}$ & $\begin{array}{l}17.8 \\
35.0 \\
48.0\end{array}$ & $\begin{array}{l}\text { ns } \\
\text { ns } \\
\text { ns }\end{array}$ & $\begin{array}{l}13.5 \\
52.3 \\
34.2\end{array}$ & $\begin{array}{r}8.0 \\
49.6 \\
41.4\end{array}$ & $\begin{array}{l}\text { ns } \\
\text { ns } \\
\text { ns }\end{array}$ \\
\hline Waist/hip ratio $(\bar{X}($ S.D. $))$ & $0.9(0.1)$ & $0.9(0.1)$ & ns & $1.0(0.1)$ & $0.9(0.1)$ & ns \\
\hline $\begin{array}{l}\text { Blood pressure } \\
\text { Systolic }(\bar{X}(\text { S.D.) }) \\
\text { Diastolic }(\bar{X}(\text { S.D. }))\end{array}$ & $\begin{array}{r}130.7(23.9) \\
79.1(13.1)\end{array}$ & $\begin{array}{r}130.9(22.2) \\
80.1(12.3)\end{array}$ & $\begin{array}{l}\text { ns } \\
\text { ns }\end{array}$ & $\begin{array}{r}126.7(20.3) \\
79.1(12.0)\end{array}$ & $\begin{array}{r}127.4(18.0) \\
80.7(10.6)\end{array}$ & $\begin{array}{l}\text { ns } \\
\text { ns }\end{array}$ \\
\hline
\end{tabular}

The data of patients used for baseline and 12-months values were not significantly different.

in $35.4 \%$ and functional pituitary tumour in $19.4 \%$; nonpituitary tumour: craniopharyngioma $10.4 \%$, meningioma $0.6 \%$ and others $2.0 \%$; Sheehan's syndrome represented $14.3 \%$, empty sella $6.9 \%$ and other causes $11.0 \%$ of the total 356 patients. GH peak concentrations were between $3-5 \mathrm{ng} / \mathrm{ml}$ in $5.9 \%$ and below $3 \mathrm{ng} / \mathrm{ml}$ in the rest. No significant differences were observed between patients of retrospective and prospective studies, except for other aetiologies $(P<0.05)$. Mean IGF-I values expressed in standard deviation scores (SDS) ranged from -6.9 to -2.9 and mean SDS of IGFBP-3 measurements from -1.9 to -1.0 compared with a reference population (25). GHD patients with one additional pituitary hormone deficiency comprised $9.1 \%$, two additional pituitary hormone deficiencies $21.9 \%$, and panhypopituitarism was diagnosed in $69.0 \%$. Treatments received for pituitary tumours were similar to those of the retrospective study: radiotherapy and surgery in $41.0 \%$, surgery alone in $29.3 \%$ and other treatments in $29.7 \%$. Mean evolution time of
GH deficiency was 8.2 years (s.D. $=6.6$; range: $2-35$ years). Physical examination data and cardiovascular risk factors of 356 patients at baseline and of 320 patients followed to the 12-month visit are shown in Tables 2-4.

Laboratory evaluation Mean complete blood analysis, electrolytes, general biochemistry and liver and kidney function were normal at baseline and at the 12-month visit (data not shown). Percentages of patients with cardiovascular risk factors not treated with lipidlowering drugs are shown in Table 4. Patients on lipid-lowering drug treatment increased from $11.7 \%$ at baseline to $17.3 \%$ at 12 months. Mean hormone values (free and total $\mathrm{T}_{4}$ and testosterone) demonstrated adequate standard hormonal substitution (data not shown).

Health-related quality of life QoL-AGHDA scores for patients at baseline were $9.4(\mathrm{CI}=8.4-10.4)$ and at 12

Table 3 Cardiovascular risk factors I (percentage).

\begin{tabular}{llcccc}
\hline & Sex & Baseline & 12 months & $\boldsymbol{P}$ \\
\hline BMI $\geq 30 \mathrm{~kg} / \mathrm{m}^{2}$ & & $\mathrm{M}$ & 34.2 & 41.4 & $\mathrm{~ns}$ \\
Waist/hip ratio & $\mathrm{M}>1$ & $\mathrm{~F}$ & 41.0 & 48.0 & $\mathrm{~ns}$ \\
& $\mathrm{~F}>0.9$ & $\mathrm{~F}$ & 30.0 & 25.4 & $\mathrm{~ns}$ \\
Hypertension $^{*}$ & & $\mathrm{M}$ & 36.2 & 34.0 & $\mathrm{~ns}$ \\
& & $\mathrm{~F}$ & 22.6 & 23.2 & $\mathrm{~ns}$ \\
& & 21.7 & 24.2 & $\mathrm{~ns}$ \\
\hline
\end{tabular}

${ }^{*}$ Hypertension was considered in patients on antihypertensive treatment at baseline and at 12 months or with blood pressure values above $140 \mathrm{mmHg}$ systolic and $90 \mathrm{mmHg}$ diastolic (40). The overall prevalence of hypertension in the Spanish population calculated in a sample of 29929 subjects aged between $15-74$ was $14.8 \%(\mathrm{Cl}: 13.3-16.2 \%: 16.5 \%$ for men $(\mathrm{Cl}$ : $14.2-18.9 \%)$ and $13.2 \%$ for women $(\mathrm{Cl}: 11.2-15.2 \%))(32)$. The overall prevalence of obesity $\left(\mathrm{BMI} \geq 30 \mathrm{~kg} / \mathrm{m}^{2}\right.$ ) was studied in a sample of 5388 subjects between $25-60$ years of age representative of different autonomous regions in Spain: $11.5 \%$ in men and $15.2 \%$ in women. In the 45-54 age group, the prevalence in men was $16.6 \%(\mathrm{Cl}: 13.0-20.1 \%)$ and in women $25.9 \%$ (Cl: $22.2 \%-29.5 \%)(31)$. 
Table 4 Cardiovascular risk factors II (percentage).

\begin{tabular}{|c|c|c|c|c|c|c|}
\hline & \multirow[b]{2}{*}{ Sex } & \multicolumn{2}{|c|}{ Baseline } & \multicolumn{2}{|c|}{12 months } & \multirow[b]{2}{*}{$\boldsymbol{P}$} \\
\hline & & $\%$ & $\bar{X}(\mathrm{~S} . \mathrm{D})$. & $\%$ & $\bar{X}($ S.D. $)$ & \\
\hline Cholesterol > $6.5 \mathrm{mmol} / \mathrm{l}$ & $\begin{array}{l}F \\
M\end{array}$ & $\begin{array}{l}31.6 \\
26.5\end{array}$ & $\begin{array}{l}7.3(0.1) \\
7.3(0.1)\end{array}$ & $\begin{array}{l}22.3 \\
18.5\end{array}$ & $\begin{array}{l}7.3(0.1) \\
7.3(0.2)\end{array}$ & $\begin{array}{l}\text { ns } \\
\text { ns }\end{array}$ \\
\hline $\begin{array}{l}\text { HDL cholesterol } \\
\quad<0.9 \mathrm{mmol} / \mathrm{l} \\
\quad<1.16 \mathrm{mmol} / \mathrm{l}\end{array}$ & $\begin{array}{l}F \\
M\end{array}$ & $\begin{array}{l}37.5 \\
26.1\end{array}$ & $\begin{array}{l}0.9(0.0) \\
0.7(0.0)\end{array}$ & $\begin{array}{l}29.2 \\
24.0\end{array}$ & $\begin{array}{l}0.7(0.0) \\
0.7(0.0)\end{array}$ & $\begin{array}{l}\text { ns } \\
\text { ns }\end{array}$ \\
\hline LDL cholesterol $>4.0 \mathrm{mmol} / \mathrm{l}$ & $\begin{array}{l}\mathrm{F} \\
\mathrm{M}\end{array}$ & $\begin{array}{l}36.1 \\
42.4\end{array}$ & $\begin{array}{l}4.8(0.1) \\
4.7(0.0)\end{array}$ & $\begin{array}{l}31.9 \\
42.1\end{array}$ & $\begin{array}{l}4.8(0.1) \\
4.6(0.0)\end{array}$ & $\begin{array}{l}\text { ns } \\
\text { ns }\end{array}$ \\
\hline Triglycerides > $2.3 \mathrm{mmol} / \mathrm{l}$ & $\begin{array}{l}F \\
M\end{array}$ & $\begin{array}{l}19.0 \\
22.9\end{array}$ & $\begin{array}{l}4.2(0.6) \\
3.7(0.2)\end{array}$ & $\begin{array}{l}16.4 \\
20.2\end{array}$ & $\begin{array}{l}3.6(0.3) \\
3.2(0.1)\end{array}$ & $\begin{array}{l}\text { ns } \\
\text { ns }\end{array}$ \\
\hline
\end{tabular}

Lipid values were taken from non-treated patients. Percentages of patients on lipid-lowering drug treatment were $11.7 \%$ at baseline and $17.3 \%$ at 12 months. Values of triglycerides, LDL and total cholesterol were statistically higher $(P<0.01)$ and those of $\mathrm{HDL}$ cholesterol statistically lower $(P<0.01)$ compared with those of a reference population composed of 133

women and 104 men aged between 50-64. Hypercholesterolaemia was present in 18\% of this reference population (32).

months were $10.0(\mathrm{CI}=8.8-11.0)$. These scores were adjusted for age and education level for comparison with the reference population scores (5.49; CI $=5.27$ $5.71)$; differences were highly statistically significant $(P<0.01)(26)$.

Health status evaluation Health status evaluation in the last year showed that GHD patients presented more non-specific joint aches and pains (44.4 vs $31.4 \%$; CI: $7.1-18.9 \%)$, nerves/depression (25.9 vs $16.4 \%$; CI: $4.4-14.6 \%$ ) and high blood pressure (22.6 vs $14.9 \%$; CI: $2.8-12.6 \%)$ than the general population, together with more hypercholesterolaemia $(33.2 \%$ vs $18 \%$; CI: $19.4-29.9 \%$ ) and diabetes mellitus (9.7 vs $3.6 \%$; CI: $2.8-9.4 \%)$. Surprisingly, varicose veins (17.1 vs $8.1 \%$; CI: 4.7-13.3\%), haemorrhoids (23.5 vs $6.4 \%$; CI: $12.4-21.8 \%$ ) and constipation (32.1 vs 6.5\%; CI: $2.0-30.7 \%$ ) were also mentioned more often by GHD patients. In contrast, patients did not present headaches more often than the general population (33.8 vs 30.4\%; not significant (ns)). No statistically significant differences were observed in baseline-referred health status compared with that at 12 months in the patient group.

In relation to health habits, there were fewer smokers among patients $(27.0 \%$ vs $34.9 \%$; CI: $2.02-12.9 \%)$. The range of education level was: no studies (38.1\%), primary education (31.8\%), secondary education $(19.6 \%)$ and higher education/university (10.4\%). Percentages for the reference population were $3.9 \%$, $45.1 \%, 38.6 \%$ and $12.4 \%$ respectively, with statistically significant differences (26). A greater degree of social isolation was not detected in our patient group.

Health-economic evaluation Direct costs were 1089.7 USD/year/patient (Table 5) and mean indirect costs 651.2 USD/year/patient (Table 6). Estimated prevalence of the disease is 1/10000 (27); thus, 3862 individuals could be affected in Spain with a population of 38.6 million according to the 1991 census. The total direct health costs of adult hypopituitary patients

Table 5 Comparison of direct health costs between the general Spanish population and Spanish hypopituitary patients with GH deficiency.

\begin{tabular}{lccccc}
\hline & $\begin{array}{c}\text { Annual hypopituitary } \\
\text { patient individual } \\
\text { health costs (USD) } \\
\text { Present study }\end{array}$ & $\begin{array}{c}\text { Annual } \\
\text { hypopituitary } \\
\text { individual health } \\
\text { costs (USD)* }\end{array}$ & $\begin{array}{c}\text { Total annual } \\
\text { hypopituitary } \\
\text { patient health } \\
\text { costs (USD) }\end{array}$ & $\begin{array}{c}\text { Annual individual } \\
\text { Spanish health } \\
\text { costs: 1993 } \\
\text { figures (USD) }\end{array}$ & $\begin{array}{c}\text { Total annual } \\
\text { Spanish health } \\
\text { costs: 1993 } \\
\text { figures (MUSD) }\end{array}$ \\
\hline Physician services & 41.6 & 36.6 & 141349 & 222.2 & 8581.3 \\
$\begin{array}{l}\text { Hospital attendance } \\
\text { (out-patients included) }\end{array}$ & 494.9 & 435.6 & 1682287 & 345.9 & 13358.6 \\
$\begin{array}{l}\text { Medication } \\
\text { Substitution (49\%) }\end{array}$ & 271.1 & & & & \\
$\begin{array}{l}\text { Concomitant (51\%) } \\
\text { Total }\end{array}$ & 282.1 & 238.5 & 921087 & - & - \\
Total & 553.2 & 248.3 & 958935 & - & - \\
\hline
\end{tabular}

* For comparison, direct health costs of hypopituitary patients of the present study were adjusted according to the 1993 RPI available figures. The total Spanish population was 38.6 millions, and the estimated prevalence of GHD in adults is 1/10 000 (27). 
Table 6 Indirect health costs. Annual days of sick leave of Spanish hypopituitary patients with GH deficiency.

\begin{tabular}{lcccr}
\hline $\begin{array}{l}\text { Years from diagnosis } \\
\text { and number of patients }\end{array}$ & $\begin{array}{c}\text { Days off from } \\
\text { work }\end{array}$ & $\begin{array}{c}\text { Mean day } \\
\text { earnings } \\
(31.6 \text { USD) }\end{array}$ & $\begin{array}{c}\text { Median days off } \\
\text { from work per } \\
\text { patient }\end{array}$ & $\begin{array}{c}\text { USD/year per } \\
\text { patient }\end{array}$ \\
\hline $1-4(n=127)$ & 4294 & 135690 & 37 & 1067.8 \\
$5-9(n=102)$ & 985 & 31126 & 9 & 305.0 \\
$10-14(n=45)$ & 741 & 23416 & 17 & 520.0 \\
$>14(n=46)$ & 578 & 18265 & 13 & 396.9 \\
Total $(n=320)$ & 6598 & 208497 & 21 & Mean: 651.2 \\
\hline
\end{tabular}

${ }^{*}$ Mean day earnings of the present study were adjusted to 1993 figures according to the RPI and unemployment data (40.9 USD/day is transformed to $31.6 \mathrm{USD} /$ day).

adjusted to 1993 data were 3.7 million USD (MUSD), a small contribution to the total Spanish direct health costs of 27470.3 MUSD (Table 5). However, when direct patient costs (expenses adjusted for comparison with available data of 1993) were compared with individuals of the general population, $35 \%$ more costs were observed (959.0 vs 711.3 USD) in patients than in the general population individuals, due mainly to drug therapies (Table 5). The Spanish total indirect costs/ year are 5330.4 MUSD (22) and the disease contributes 2.5 MUSD/year (considering the estimated prevalence of 3862 individuals). Indirect costs (loss of productivity) when distributed by evolution time showed a decrease from the early years to ten years when a slight increase was observed (Table 6). The global estimated cost of the disease (direct and indirect costs) is 6.2 MUSD/year.

Thirty-seven patients were lost during follow-up: 4 were included in a clinical trial with $\mathrm{GH}, 5$ did not comply with the protocol, 1 suffered a stroke with haemiplegia, 19 missed the control visit but were checked as alive, and $8(2.2 \%)$ died during the observation period -3 from cardiovascular disease, 3 from malignant disease (44\%) and 2 from other causes (sepsis and encephalitis).

\section{Discussion}

To our knowledge, this cross-sectional study is the largest (926 patients) conducted in GH-deficient adult patients. Demographic, aetiologic and clinical features of other studies are confirmed (7, 9, 13, 27-29). Cardiovascular disease has been reported to be the main cause of increased mortality in patients with hypothalamic-pituitary disease (28). This study is not an epidemiological one on mortality, but does permit us to compare the causes of death among these patients and the general population. The death rate from cardiovascular disease in the Spanish census was 23\% for the same age (30), lower, therefore, than the $44 \%$ found in patients in the prospective study.

Since statistical comparison of demographic, aetiologic and analytical data is similar between crosssectional and longitudinal study patients, it may be assumed that results of longitudinal follow-up can be applied to the sample as a whole. The diagnosis of GH deficiency in the 926 patients is corroborated by both lack of response to $\mathrm{GH}$ stimulation test $(<3 \mathrm{ng} / \mathrm{ml}$ in more than $93 \%$ of patients and below $5 \mathrm{ng} / \mathrm{ml}$ in the rest) and another associated pituitary hormone deficiency. Abnormally low IGF-I and IGFBP-3 levels obtained in the group of patients followed longitudinally confirms GH deficiency. Standard substitution of other pituitary hormone deficiencies demonstrated by clinical and laboratory controls permits us to assume that abnormal findings in these patients are attributed mainly to GH deficiency. Obesity (BMI $\geq 30 \mathrm{~kg} / \mathrm{m}^{2}$ ) was present in $41.0 \%$ of women and $34.2 \%$ of men in the present study, clearly higher compared with $25.9 \%$ and $16.6 \%$, respectively, of the Spanish population at the same age $(31,32)$. This degree of obesity is maintained at 12 months of follow-up. Obesity in these patients was of the central type, a well-known risk factor for cardiovascular disease. Waist-hip ratio was $>1$ in $30 \%$ of the men and $>0.9$ in $36 \%$ of the women.

The prevalence of hypertension, a further risk factor, is somewhat higher in our patients, $22.6 \%$ in men and $21.7 \%$ in women vs $14.9 \%$ in our reference population, which ranges from 12.2 to $16.2 \%(32,33)$. Patients of the study not treated with lipid-lowering drugs presented higher total and LDL cholesterol and lower HDL cholesterol levels compared with the reference population; these were maintained throughout the study, albeit with a slight tendency to decrease, since the percentage of patients under treatment increased in the follow-up visit. These findings of an increase in cardiovascular risk factors confirm those of other authors $(13,29)$.

GH-deficient adult patients had previously proved to have an HRQoL below that of the reference population, assessed by generic $(7-9,34-38)$ and specific (26) tests. In the present study, QoL-AGHDA and direct questioning about perceived health confirm that these GHdeficient patients have worse HRQoL and, at the same time, report greater problems of non-specific joint aches and pains, nerves/depression and diabetes mellitus than the reference population. Furthermore, the laboratory and physical data collected in the study corroborate that these patients also present greater problems of hypertension and dyslipaemia. Despite a history of hypopituitary 
disease and its treatment, and conversely to what one would expect, the patients do not present a higher prevalence of headaches than the reference population. Neither do they present greater impaired social status (i.e. income, permanent job, etc.), as described by other authors, which may be explained by the fact that these patients acquired the deficiency in adulthood $(12,39)$.

One aspect which, to date, has not received much attention in these patients is the economic consequences of their disease. The cost of one specific disease in relation to its prevalence takes into account all the existing cases during a certain time period, normally one year, and extrapolating the costs generated by the patients sample followed to the estimated prevalence. Calculation of direct and indirect costs of these patients over one year constitutes a good approach to the economic impact that may be generated by their disease, although it could be argued that cost-of-illness calculations are seriously deficient in not including intangible costs (21). The contribution of this condition represents a small part of the direct costs of the overall Spanish Health Service expenditure. When the health costs per person are compared, it can be seen that the patients account for $35 \%$ more than the national average. The type of care in which the difference is most significant is pharmacology in which the national average expenditure per person is more than tripled. On the other hand, where out-patient care is concerned, their consumption is much lower than the national average, possibly due to the fact that follow-up of this kind of patient is principally carried out in a hospital setting. In comparison to another pharmaco-economic study conducted in Sweden on the same type of patient, the cost was somewhat higher (15), although calculations of direct costs in that study may have included the cost of the first year (surgery and/or radiotherapy) which we did not include as we followed patients with GHD for more than one year, but an increase in direct costs was seen in our study of patients compared with the general population.

The loss of productivity is not an ideal pharmacoeconomic approach and has been widely criticized because it does not include the impact of collective groups such as pensioners that are not integrated in the labour market. Neither is it valid in societies with high unemployment rates, such as ours. In the present study, calculation of costs was adjusted to the unemployment rate published. The contribution of the study patients to the Spanish total indirect health costs is low and, in contrast to other chronic diseases, is higher in the first years after diagnosis, which could be interpreted as adaptation to the disease. When the disease prevalence is considered (27) and extrapolated to the total prevalence in Spain, the overall estimated cost is 6.2 million dollars; this cost is approximate since intangible costs and premature mortality were not evaluated.

Eight of the three hundred and fifty-six patients died during follow-up, which represents a 2.6-fold increase in expected mortality of the general population: $850 /$ 100000 inhabitants $(2.2 \%$ vs $0.85 \%)$ (30). Three died from cardiovascular disease, which indicates a higher incidence, with data similar to those found in the retrospective study when compared with the general population.

In conclusion, this study confirms that GH deficiency acquired in adulthood in a large population in Spain presented demographic, aetiological, clinical and laboratory characteristics similar to those found in other countries. Similarly, the higher incidence of both risk factors and cardiovascular mortality in this group of patients compared with the general Spanish population is confirmed.

Further long-term studies are required to confirm the risk of cardiovascular mortality and the influence of $\mathrm{GH}$ treatment on its future prevention. Understanding of the economic cost of hypothalamic-pituitary disease in adults with untreated GH deficiency is essential for posterior comparison with that of other chronic diseases and will permit future assessment of the cost-benefit ratio of substitution $\mathrm{GH}$ therapy in these patients.

\section{Acknowledgements}

We gratefully acknowledge the technical assistance of Mr Xavier Bona and Mr Joaquin Campbell of Pharmacia \& Upjohn (Spain) in the study design and statistical analysis. We thank Ms Rosalia Rego and Ms Eva Peña for monitoring, Ms Christine O'Hara for manuscript review, and patients for their valuable collaboration. This work was supported by a grant from Pharmacia \& Upjohn, Spain.

\section{The Collaborative ODA Group consists of:}

Dr J A Vázquez, Dr Y García, H de Cruces; Dr M Rigla, Dr A Chico, H Sant Pau; Dr F Escobar-Jiménez, Dr J Peñafiel, Dr E Torres, H Clínico de Granada; Dr P RuizValdepeñas, Dr L García-Pinar, Dr A Rodríguez, H 12 de Octubre; Dr J Mesa, Dr R Burgos, H Vall d'Hebrón; Dr J M Gómez, Dr N Gómez, H de Bellvitge; Dr E Vilardell, Dr A Costa, H Clínic de Barcelona; Dr J Moreiro, Dr H García, Dr L Arribas, H Son Dureta; Dr A Leal, Dr R Astorga, Dr H Silva, H Virgen del Rocío; Dr F Piñón, Dr A Gilsanz, H La Fé; Dr L Morcillo, Dr J Pérez, H Universitario de Tenerife; Dr I Salinas, H Germans Trias i Pujol; Dr J García-Arnés, Dr F Tinahones, Dr G Fernández-Madero, Dr F Soriguer, H Carlos Haya; Dr J L Herrera-Pombo, Dr O Sánchez-Vilar, Dr S Azriel, Fundación Jiménez Díaz; Dr P Benito, Dr A Gálvez, H Reina Sofía; Dr V GarcíaMayor, Dr C Páramo, H Xeral de Vigo; Dr J Freijanes, H Marqués de Valdecilla; Dr F Cordido, H Juan Canalejo; Dr J Tébar, Dr G Liante, Dr JC Madrid, Dr AM Hernández, H Virgen de la Arrixaca; Dr W Ricart, Dr J M Fernández-Real, Dr J Biarnes, H Josep Trueta; Dr R Albero, H Miguel Servet; Dr B Barceló, Dr T Lucas, H Puerta de Hierro; Dr M Santiago, H La Paz; Dr J 
Anglada, Dr C del Pozo, H Mutua de Terrassa; Dr R Ezquerra, Dr L Irigoyen, Dr J Escalada, H Santiago Apóstol; Dr E Faure, Dr J Ocón, H Clínico de Zaragoza; Dr E Ruiz, H General Yagüe; Dr C Hernández, Dr J Ma Recio, H Virgen de la Candelaria; Dr L Forga, Dr E Anda, H de Navarra; Dr J A García, Dr C Castel, H Sta Cristina; Dr M Suárez, Dr R Aguado, H Virgen Blanca; Dr M Aguilar, Dr I Gavilán, H Puerta del Mar; Dr A Ojeda, Dr J Novoa, H Insular de las Palmas; Dr J M Miralles, Dr L Santiago, Dr P Álvarez, H Clínico de Salamanca; Dr A Charro, Dr A Durán, Dr M Ballesteros, H Clínico de Madrid; Dr J Díaz, Dr JA Álvarez, Dr F Morales, H Infanta Cristina de Badajoz; Dr PL de Pablo, Dr C Santana, Hospital Ntra Sra del Pino.

\section{References}

1 Cuneo RC, Salomon F, McGauley GA \& Sönksen PH. The growth hormone deficiency syndrome in adults. Clinical Endocrinology 199237 387-397.

2 Jørgensen JOL, Pedersen SA, Thuesen L, Jørgensen J, IngemannHansen T, Skakkebaek NE et al. Beneficial effects of growth hormone treatment in GH-deficient adults. Lancet 198911221 1225 .

3 Hoffman DM, O'Sullivan AJ, Freund J \& Ho K. Adults with growth hormone deficiency have abnormal body composition but norma energy metabolism. Journal of Clinical Endocrinology and Metabolism $19958072-77$.

4 De Boer H, Blok GJ \& van der Veen VA. Clinical aspects of growth hormone deficiency in adults. Endocrine Reviews 199516 63-86.

5 Hoffman DM \& Ho K. Growth hormone deficiency in adults. Endocrinologist 19977 233-237.

6 Carroll PV, Christ ER and the members of Growth Hormone Research Society Scientific Committee: Bengtsson B-A, Carlsson LM, Christiansen JS, Clemmons D, Hintz R, Ho K, Laron Z, Sizonenco P, Sonksen PH, Tanaka T, \& Thorner M. Growth hormone deficiency in adulthood and the effects of growth hormone replacement: a review. Journal of Clinical Endocrinology and Metabolism 199883 382-395.

7 Mårdh G, Lundin K, Borg G, Jonsson B \& Lindberg A. Growth hormone replacement therapy in adult hypopituitary patients with growth hormone deficiency: combined data from 12 European placebo-controlled trials. Endocrinology and Metabolism 1994 (Suppl A) 43-49.

8 Burman P, Broman JE, Hetta J. Wiklund I, Erfurth EM, Hagg E et al. Quality of life in adults with growth hormone (GH) deficiency: response to treatment with recombinant human $\mathrm{GH}$ in a placebocontrolled 21-month trial. Journal of Clinical Endocrinology and Metabolism 199580 3585-3590.

9 Cuneo RC, Judd S, Wallace JD, Perry-Keene D, Burger H, Lim-Tio S et al. The Australian multicenter trial of growth hormone $(\mathrm{GH})$ treatment in GH-deficient adults. Journal of Clinical Endocrinology and Metabolism 199883 107-116.

10 Johansson G, Rosen T, Bosaeus L, Sjostrom L \& Bengtsson B-A. Two years of growth hormone $(\mathrm{GH})$ treatment increases bone mineral content and density in hypopituitary patients with adult onset GH deficiency. Journal of Clinical Endocrinology and Metabolism 199681 2865-2873.

11 Jørgensen JOL, Thuesen L, Muller J, Ovesen P, Skakkebaek NE \& Christiansen JS. Three years of growth hormone treatment in growth hormone-deficient adults: near normalization of body composition and physical performance. European Journal of Endocrinology $1994130224-228$.

12 Attanasio AF, Lamberts SWJ, Matranga AMC, Birkett MA, Bates PC, Valk NK et al. Adult growth hormone-deficient patients demonstrate heterogeneity between childhood onset and adult onset before and during human GH treatment. Journal of Clinical Endocrinology and Metabolism 199782 82-88.

13 Cuneo RC, Salomon F, Watts GF, Hesp R \& Sonksen PH. Growth hormone treatment improves serum lipids and lipoproteins in adults with growth hormone deficiency. Metabolism: Clinical and Experimental 199342 1519-1523.

14 De Boer H, Blok GJ, Voerman HJ, Philips M \& Schouten JA. Serum lipid levels in growth hormone-deficient men. Metabolism: Clinical and Experimental 199443 199-203.

15 Ehrnborg C, Rosén T, Roijen LV, McDonnell J, Rutten FFH \& Bengtsson BA. Cost of illness study of adult hypopituitary patients. 79th Annual Endocrine Society Meeting. Minneapolis 1997 Poster P03-100.

16 Doward LC. The development of the AGHDA: a measure to assess quality of life of adults with growth hormone deficiency. Quality of Life Research 19954 420-421.

17 Holmes SJ, McKenna SP, Doward LC, Hunt SM \& Shalet S. Development of a questionnaire to assess the quality of life of adults with growth hormone deficiency. Endocrinology and Metabolism 19952 63-67.

18 McKenna SR \& Doward LC. Ouality-of-life assessment of adults with growth hormone deficiency. PharmacoEconomics 19946 434-441.

19 Realidad social en España. Capítulo 7. Centro de Investigación sobre la Realidad Social (CIRES). Bilbao 1994. Monografía encuesta de salud española. Fundación Banco Bilbao-Vizcaya.

20 Drummond M. Cost-of-illness studies. A major headache? PharmacoEconomics 19922 1-4.

21 Kotsanos JG \& Zeckel M. Dollars and sense: learning the health economics language to survive. Endocrinologist 19977 267-270.

22 Gisbert R, Brosa M, Figueras M, Mindan E \& Rovira J. 1997 El coste de la enfermedad en España. El coste de las enfermedades cardiovasculares. Monografia MSD. Madrid.

23 Kobelt G, Eberhardt K, Jönsson L \& Jönson B. Economic consequences of the progression of rheumatoid arthritis in Sweden. Arthritis and Rheumatism 199942 347-355.

24 Hoffman C, Rice D \& Sung HY. Persons with chronic conditions: their prevalence and costs. JAMA 1996276 1473-1479.

25 Granada ML, Murillo J, Llopis MP, Lucas A, Salinas I, Cuatrecases $\mathrm{G}$ et al. Diagnostic efficiency of serum IGF-I, IGFBP-3 and urinary $\mathrm{GH}(\mathrm{UGH})$. Measurements in the diagnosis of adult growth hormone deficiency (GHD). Importance of appropriate reference population. IV European Congress of Endocrinology, Seville 19981 $1-124$.

26 Badia X, Lucas A, Sanmartí A, Roset M \& Ulied A on behalf of the collaborative group. One-year follow-up of quality of life in adults with untreated growth hormone deficiency. Clinical Endocrinology $199849765-771$.

27 Lamberts WJS, Walk NR \& Bineverts A. The use of growth hormone in adults: a changing scene. Clinical Endocrinology 1992 $37111-115$.

28 Rosén T \& Bengtsson B-A. Premature mortality due to cardiovascular disease in hypopituitarism. Lancet 1990336 285-288.

29 Rosén T, Edén S, Larson G, Wilhelmsen L \& Bengtsson B-A. Cardiovascular risk factors in adults with growth hormone deficiency. Acta Endocrinologica 1993129 195-200.

30 Instituto Nacional de Estadística (INE). 1993 Tablas de mortalidad española, pp 134-149. Madrid.

31 Aranceta J, Pérez C, Serra L, Ribas L, Quiles J, Vioque J et al. Prevalencia de la obesidad en España: estudio SEEDO'97. Medicina Clinica $1998111441-445$.

32 Generalitat de Catalunya, Plà de Salut de Catalunya. Departament de Sanitat i Seguretat Social. $1^{\text {a }}$ De. Barcelona 1993, 60-80.

33 Tresserras R \& Pardell H. Prevalencia e importancia sanitaria de la Hipertensión Arterial. Anales de Medicina Interna 19907 (Suppl 3) $1-6$.

34 Rosén T, Wirén L, Wilhelmsen L, Wiklund I \& Bengtsson B-A. Decreased psychological well-being in adult patients with growth hormone deficiency. Clinical Endocrinology 199440 $111-116$. 
35 McGauley GA, Cuneo RC, Salomon F \& Sönksen PH. Psychological well-being before and after growth hormone treatment in adults with growth hormone deficiency. Hormone Research 1990 $3352-54$

36 Wirén L, Bengtson B-A \& Johannsson G. Beneficial effects of longterm $\mathrm{GH}$ replacement therapy on quality of life in adults with $\mathrm{GH}$ deficiency. Clinical Endocrinology 199848 613-620.

37 Almqvist O, Thoren M, Sääf M \& Eriksson O. Effects of growth hormone substitution on mental performance in adults with growth hormone deficiency: a pilot study. Psychoneuroendocrinology $198611347-352$.

38 Wallymahmed ME, Foy P, Shaw D, Hutcheon R, Edwards RHT \& MacFarlane IA. Quality of life, body composition and muscle strength in adult growth hormone deficiency: the influence of growth hormone replacement therapy for up to 3 years. Clinical Endocrinology 199747 439-446.

39 Rikken B, van Busschbach J, le Cessie S, Manten W, Spermon T, Grobbee $\mathrm{R}$ et al. Impaired social status of growth hormonedeficient adults as compared with controls with short or normal stature. Clinical Endocrinology 199543 205-211.

40 Joint National Committee on Detection, Evaluation and Treatment of High Blood Pressure. The Sixth Report (JNC VI). Archives of Internal Medicine 1997157 2413-2439.

Received 21 May 1999

Accepted 27 July 1999 